Chase Ollis

\title{
ACRL honors the 2019 award winners, part 2

\author{
A recognition of professional development
}

\section{SUNY Geneseo receives CLS Innovation in College Librarianship Award}

Bill Jones and Ben Rawlins, both of the State University of New York (SUNY)-Geneseo Milne Library, have been named the 2019 recipients of the College Libraries Section (CLS)

Innovation in College Librarianship Award for their work on the Openly Available Sources Int e g r a t e d Search (OASIS) project. Jones is digital resources and systems librarian, and Rawlins is library director.

This annual award honors ALA members who have demonstrated a capacity for innovation in their work with undergraduates, instructors, and /or the library community.

Their \$1,000 award and plaque, donated by SCELC, will be presented during the CLS Friday Night Feast at the 2019 ALA Annual Conference in Washington, D.C.
OASIS is an open educational resource search tool that makes the discovery of open content easier by (currently) searching 72 sources containing more than 170,000 records. It searches multiple vetted sources for materials, most of which are in the public domain or openly licensed.

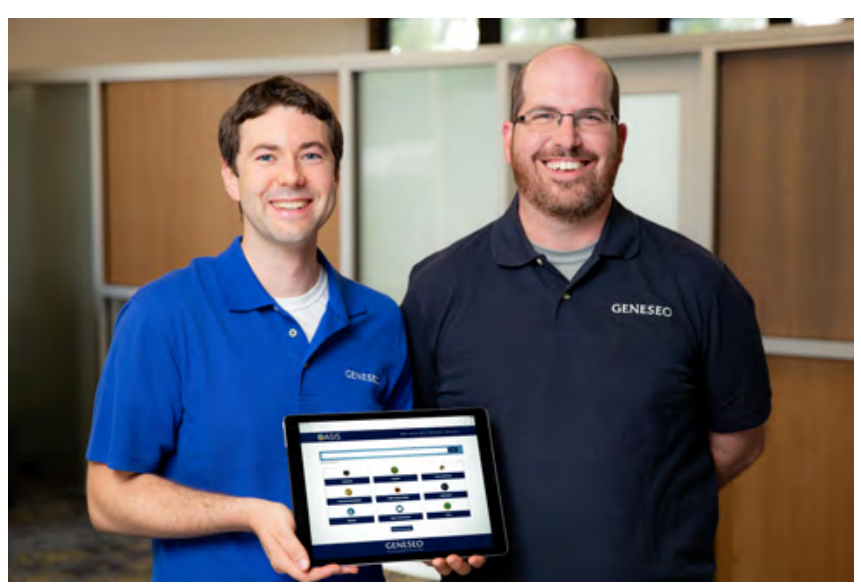

Bill Jones and Ben Rawlins of the SUNY-Geneseo Milne Library.

For example, users can search for materials from MIT OpenCourseWare, OpenStax, Open Tex tbook Library, Ted Talks, and the Directory of Open Access Books, among many others, from one interface.

"The OASIS search tool was developed to address the issue of college affordability," said award chair Susan A. Schreiner, access services librarian at Pittsburg State University. "This tool provides faculty the means to provide free textbooks and other

Chase Ollis is ACRL program officer, email:collis@ala.org (c) 2019 Chase Ollis 
resources and reduces the financial burden on students leading to a positive impact on student learning and retention.

"Institutions across the world have added OASIS to their websites and their communities can now search open access materials with ease and speed," continued Schreiner. "The committee felt the timeliness and depth of the search tool, the willingness of the creators to share it with other institutions around the world, and the financial impact it has on students all over the world, make it a clear winner for this year's award."

\section{Raish named Routledge Distance Learning Librarianship Conference Sponsorship Award winner}

Victoria (Torrie) Raish, online learning librarian at Pennsylvania State University,

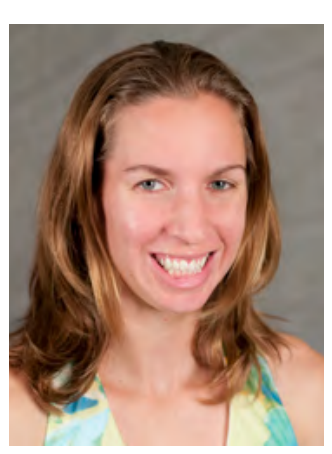

Victoria (Torrie) Raish has been named the recipient of the Routledge Distance Learning Librarianship Conference Sponsorship Award.

This annual award, sponsored by Routledge/ Taylor \& Francis Group, and administrated by the

Distance Learning Section (DLS), honors an ACRL member working in the field of, or contributing to, the success of distance learning librarianship or related library service in higher education. Routledge/ Taylor \& Francis Group will present the $\$ 1,200$ award and plaque at the ALA Annual Conference.

"Torrie Raish has made significant contributions to the field of distance librarianship," said award cochairs Melissa Atkinson of Abilene Christina University and Cynthia Thomes of the University of Maryland University College. "Her various efforts include creating an embedded librarian program and information literacy repository, starting an equivalent access e-book program, and collaborating with other departments at Penn State to start a digital badge initiative.

"Her publications include peer-reviewed journal articles, book chapters, invited papers, and conference proceedings, and she has given numerous presentations at the international, national, state, and local level," continued Atkinson and Thomes. "Furthermore, her collaborations with departments and stakeholders at her institution have given online students greater access to the resources they need. Torrie is a leader on her campus, and her work to serve distance learners is being increasingly and deservedly recognized."

\section{Oakleaf wins IS Miriam Dudley Instruction Librarian Award}

Megan Oakleaf, associate professor and director of instructional quality at Syracuse University, is the winner of the Instruction Section's

(IS) Miriam Dudley Instruction Librarian Award. The award honors Miriam Dudley, whose efforts in the field of information literacy led to the formation of IS. The honor recognizes a librarian who

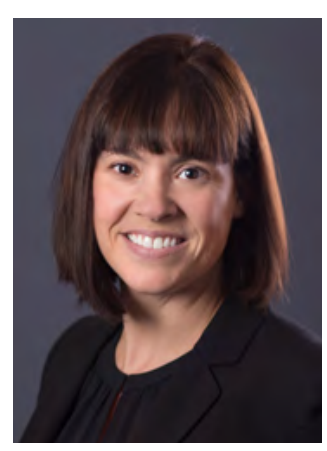

Megan Oakleaf has made a significant contribution to the advancement of instruction in a college or research library environment.

The award consists of a $\$ 1,000$ award and a plaque.

"Megan Oakleaf's career has been dedicated to shining a light on student learning, assessment strategies, and program development in libraries for two decades," said award chair Merinda Kaye Hensley of the University of Illinois at Urbana-Champaign. "Her efforts to connect the praxis of library instruction to higher educational student 
learning goals is demonstrated through the classroom tools, pedagogies, and creative thinking she has so generously shared through her many workshops, keynote presentations, and consultation work.

"From 2007 to 2016, Megan made a lifetime impact on those who attended the assessment track of the ACRL Information Literacy Immersion Program, where she developed curriculum and led conversations that initiated librarians into the complexities of what needs to be assessed and why," continued Hensley.

"Her robust body of scholarship has informed and helped to lead instructors down the path of gathering evidence of student learning at their own institutions including the ACRL publication, 'The Value of Academic Libraries: A Comprehensive Research Review and Report' (2010). Indeed, Megan's contributions to librarianship are vast and colorful, and as one of her nominators stated, she is 'an inspiration, a role model, and a boundary breaker.'”

\section{Oregon State University Undergrad Research and Writing Studio wins IS Innovation Award}

The Oregon State University (OSU) Libraries and Press has been selected to receive the Instruction Section (IS) Innovation Award for its Undergrad Research and Writing Studio, a dynamic and flexible space where students can develop skills in information literacy, media literacy, data literacy, and rhetoric and com- position. The Studio was implemented by a team of writing center and library faculty, including Dennis Bennett, Chris Ervin, Uta Hussong-Christian, Jane Nichols, Hannah Rempel, and Beth Filar Williams, and has grown through ongoing collaboration into a team of librarians, writing center staff, and media specialists.

The annual award recognizes a project that demonstrates creative, innovative, or unique approaches to information literacy instruction or programming. Donated by EBSCO Information Services, the award consists of a plaque and cash prize of $\$ 3,000$.

The Undergrad Research and Writing Studio is focused on hands-on and experiential learning, with help delivered at the point of need. It has allowed librarians at the OSU Libraries and Press to reimagine the traditional one-shot in first-year composition and across the curriculum, while also enriching the learning environment and extending the reach and impact of the university Writing Center.

"Oregon State University's Undergrad Research and Writing Studio demonstrates an innovative and grounded approach to the peer education model by a meaningful collaboration between the library and writing center," said award committee chair Jo Angela Oehrli of the University of Michigan. "The Studio allows peers to consult one-on-one, in small group sessions, or as whole classes on topics such as information literacy, media literacy, 
data literacy, and rhetoric and composition. Their work is deeply grounded in pedagogical best practices and offers an exemplary model for similar programs in libraries looking to innovate and collaborate in cross-campus spaces. This program has led to an increase in students receiving help, including growth among historically marginalized populations."

\section{RBMS Leab Exhibition award winners}

The Rare Books and Manuscripts Section (RBMS) has selected six winners, three honorable mentions, and a notable citation for the Katharine Kyes Leab and Daniel J. Leab American Book Prices Current Exhibition Awards.

The awards, funded by an endowment established by Katharine Kyes Leab and Daniel J. Leab, editors of American Book Prices Current, recognize in five categories outstanding printed exhibition catalogs and guides, and electronic exhibitions, produced by North American and Caribbean institutions. The winning catalogs will be on display at the 2019 RBMS Conference Booksellers' Showcase in Baltimore.

\section{Division One (expensive)}

Division One Winner: University of Alberta's Bruce Peel Special Collections Library for "Experiment: Printing the Canadian Imagination: Highlights from the David McKnight Canadian Little Magazine and Small Press Collection," curated by David McKnight.

"This catalogue makes a significant contribution to scholarship on Canadian little magazines and small press and micro-press imprints," said Anna Chen, chair of the RBMS Exhibition Awards Committee and head librarian at the University of California-Los Angeles Clark Library. "While it focuses on one press, the Coach House Press, the catalogue also highlights many smaller and lesserknown presses and magazines, offering audiences a refreshing deep dive into the production of Canadian Modernist poetry and avant-garde literature. The committee also praised the catalogue's striking visual design choices, which evoke the designs of the exhibition items themselves."

Division One honorable mention: The Getty Research Institute for "Artists and Their Books/Books and Their Artists," curated by Marcia Reed and Glenn Phillips.

"The committee wishes to recognize this substantial catalogue's luxurious design, from subtly textured pages to sharp photography and generous layout, culminating in a beautiful showcase for artists' books," noted Chen.

\section{Division Two (moderately expensive)}

Division Two winner: University of Miami Lowe Art Museum and University of Miami Libraries for "Antillean Visions; or, Maps and the Making of the Caribbean: An Exhibition of Cartographic Art at the Lowe Art Museum, University of Miami," curated by Casey Elinor Lue, Timothy Norris, William Pestle, Diana Ter-Ghazaryan, Nathan Timpano, and Ashli White.

"The committee was impressed by this catalogue's sensitive treatment of conquest and contested dominance, achieved through an interdisciplinary diversity of voices and perspectives," stated Chen. "It stood out, moreover, for its accessible and thought-provoking presentations of maps in both informational and aesthetic ways, as well as its use of multiple languages to underscore its arguments about the international impacts of cartography."

\section{Division Three (inexpensive)}

Division Three winner: Penn State Libraries Eberly Family Special Collections for "Field Guide to Fairy-Tale Wolves," curated by Clara Drummond.

"The committee was delighted by this entry's innovative take on the exhibition catalogue format with its cheeky 'field guide' structure, which gives new meaning to the concept of the catalogue as a 
companion to a physical exhibition, and adds an interactive dimension to the exhibition experience," Chen said.

Division Three honorable mention: Providence Public Library Special Collections for "HairBrained," curated by Sussy Santana, Angela DiVeglia, Kate Wells, and Jordan Goffin.

"This entry creatively and productively expands the boundaries of the exhibition catalogue by presenting original poetry that interprets and speaks in dialogue with the items in the exhibition," noted Chen. "The catalogue's visual design, moreover, makes the most of each compact page with vibrant, readable colors."

Division Three notable citation: Washington University Libraries Julian Edison Department of Special Collections for "The Monster's Library; An Exhibition Curated by Students Enrolled in Frankenstein, Origins and Afterlives," curated by Amy Pawl, Erin Sutherland, Corinna Treitel, and students enrolled in" Frankenstein: Origins and Afterlives."

"The committee felt that this entry deserves a citation for its clever and self-referential library-oriented thematic structure as a framework to explore Mary Shelley's Frankenstein as a 'book made of books," stated Chen. "In particular, the committee wishes to recognize the extensively collaborative work underpinning this joint project, which emerged from a student-curated exhibition as part of a university course."

\section{Division Four (brochures)}

The committee selected two co-winners in Division Four (brochures).

Division Four co-winner: Austin History Center, Austin Public Library for "Taking it to the Streets: A Visual History of Protest and Demonstration in Austin," curated by Molly Hults and Amanda Jasso.

"The committee praised this brochure's accessibility to a wide audience," Chen said. "The well-chosen photographs radiate energy, providing an invigorating way in to the exhibition itself. Moreover, the brochure included call numbers in the photographs themselves, providing clear references for audiences wishing to research the collections further."

Division Four co-winner: University of Pennsylvania Libraries Kislak Center for Special Collections, Rare Books and Manuscripts for "Ok, I'll Do It Myself," curated by Kislak Center staff.

"The committee was taken with the innovative format of this exhibition guide, which includes eight souvenir postcards, accordion-folded and perforated to encourage interactivity and multiple kinds of circulation and use," noted Chen.

\section{Division Five (electronic exhibition)}

The committee selected one winner and one honorable mention in Division Five (electronic exhibition).

Division Five winner: University of Victoria Libraries for "Volatile Attractions: Saul Holiff, Johnny Cash, and Managing a Music Legend," curated by Samantha MacFarlane.

"This digital exhibition incorporated an impressive range of photographs, audio recordings, and video clips to take advantage of the multimedia online platform," stated Chen. "The committee also praised its multiple modes of navigation, and especially appreciated that the items were fully digitized, providing research value beyond the life of the exhibition."

Division Five honorable mention: University of Delaware Library for "Things Aren't What They Seem: Forgeries and Deceptions from the UD Collections," curated by Alexander Johnston.

"The committee wishes to recognize this exhibition for its extensively contextualized and substantial content covering a wide-ranging historical period," said Chen. "It will surely serve as a rich resource for interdisciplinary teaching and research."

For more information regarding the ACRL RBMS Katharine Kyes Leab and Dan- 
iel J. Leab "American Book Prices Current" Exhibition Awards, including a complete list of past recipients, please visit the awards section of the ACRL website.

\section{STS Oberly Award goes to Karlen and Pellack}

Douglas Karlen, research soil scientist (retired) at the United States Department of Agriculture Agricultural Research Service, and Lorraine Pellack, head of the University Library research services department at Iowa State University, have been selected as the recipients of the Science and
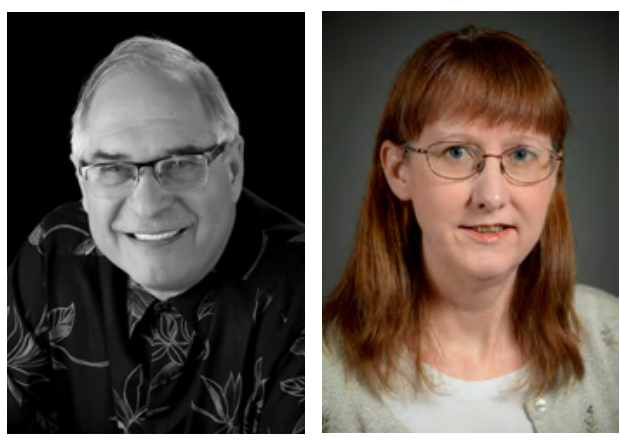

Douglas Karlen and Lorraine Pellack

Technology Section (STS) Oberly Award for Bibliography in the Agricultural or Natural Sciences for their article "Iowa Crop Variety Yield Testing: A History and Annotated Bibliography."

The award will be presented during the 2019 ALA Annual Conference.

The article, and the accompanying annotated bibliography, provides a historic account of crop varietal testing in Iowa, presented in chronological order followed by sections devoted to specific crops. It is designed to provide guidance to other researchers and anyone interested in learning more about the development of variety testing.

"This publication exemplifies the spirit of the award," said award cochairs Sara Scheib of the University of Iowa and Zoe Pettway Unno of the University of Southern California. "The comprehensive article provides historical context and the exhaus- tive accompanying annotated bibliography identifies and makes discoverable critical primary source literature in the field of agriculture.

"Due to the rich and extensive history of crop variety yield testing in Iowa, there are sources that cannot be found by searching Google or even specialized research databases," continued Scheib and Unno. "These resources were acknowledged and included when possible. The annotated bibliography provides details on the scope of coverage of each source that are extremely useful to researchers. Finally, the open access publication of the article in a top international agriculture journal ensures it will reach the target audience and continue to be a valuable resource for years to come."

The Oberly Award was established in 1923 in memory of Eunice Rockwood Oberly, librarian of the Bureau of Plant Industry, United States Department of Agriculture from 1908 to 1921. She was the Bureau of Plant Industry's representative to the Congressional Joint Commission on Reclassification of Government Employees and was instrumental in gaining a fairer recognition of library activities. This biennial award is given in odd-numbered years for the best English-language bibliography in the field of agriculture or a related science.

\section{Kruse wins WGSS Career Achievement Award}

Carrie Kruse, director of College Library, user experience, and library spaces at the University of Madison-Wisconsin, has been selected as the winner of the Women and Gender Studies Section (WGSS) Career Achievement Award. The award honors significant long-standing contributions to women and gender studies in the field of librarianship over the course of a career.

A plaque and $\$ 750$ award, donated by Duke University Press, will be presented to Kruse at a WGSS event during the ALA Annual Conference. 
"Carrie Kruse has been a proponent of Women's Studies and Women and Gender Studies librarianship throughout her career," said award chair Dolo-

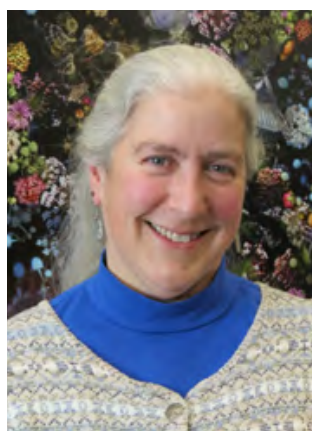

Carrie Kruse res Fidishun, head librarian at Penn State-Abington. "She has mentored countless librarians and has been extremely active in WGSS where, among other accomplishments, she was a driving force behind the WGSS Core Books project. Most importantly, as a library administrator she has demonstrated her support for our community in ways that raised awareness of our discipline."

\section{Chou and Pho win WGSS Significant Achievement Award}

Rose L. Chou, budget and personnel manager at American University, and Annie Pho, instruction coordinator and assessment librarian at the University of San Francisco, are the winners of the Women and Gender Studies Section (WGSS) Award for Significant Achievement in Women and Gender Studies Librarianship. The WGSS award honors a significant or one-time contribution to women and gender studies librarianship.

A plaque and $\$ 750$ award, donated by Duke University Press, will be presented to Chou and Pho at a WGSS event during the ALA Annual Conference.

"Chou's and Pho's book Pushing the Margins: Women of Color and Intersectionality in LIS is an extremely important contribution to our discipline, bringing critical thought and knowledge for consideration at a time when a focus on diversity and inclusion is greatly needed," said award chair Dolores Fidishun, head librarian at Penn State-Abington. "Their emphasis on intersectionality will help all of us in LIS grow as we learn about ways in which multiple social and cultural identities impact individual experience. It is a must read for any librarian!"

Using intersectionality as a framework, Pushing the Margins: Women of Color and Intersectionality in LIS explores the experiences of women of color in library and information science (LIS). With roots in black feminism and critical race theory, intersectionality studies the ways in which multiple social and cultural identities impact individual experience.

Libraries and archives idealistically portray themselves as egalitarian and neutral entities that provide information equally to everyone, yet these

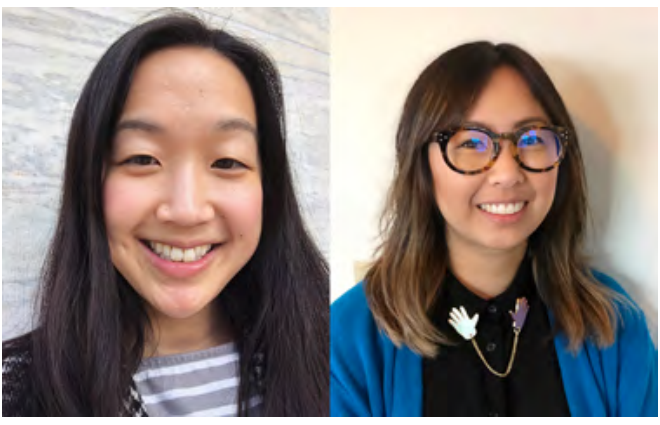

Rose L. Chou and Annie Pho

institutions often reflect and perpetuate societal racism, sexism, and additional forms of oppression. Women of color who work in LIS are often placed in the position of balancing the ideal of the library and archive providing good customer service and being an unbiased environment with the lived reality of receiving microaggressions and other forms of harassment on a daily basis from both colleagues and patrons. This edited collection examines how lived experiences of social identities affect women of color and their work in LIS. $\not 2$ 